811.161.1'374(497.11)6'19/2066

https://doi.org/10.18485/sj.2018.23.1.43

МАЈА В. ПАВЛОВИЋ-ШАЈТИНАЦ*

Универзитет Привредна академија

Правни факултет за привреду и правосуђе
Оригинални научни рад

Примљен: 04. 01. 2018.

Прихваћен: 29. 01. 2018.

\title{
О ДВЕ ЛЕКСИКОГРАФСКЕ КОНЦЕПЦИЈЕ
}

Предмет овог рада је анализа лексикографске концепције Речника рускосрпског М. Анђелковића (1903) у његовом тадашњем руско-српском лексикографском окружењу и Основног руско-српског речника Р. Маројевића (2016). Како ова два речника дели нешто више од сто година паралела њихових структура могла би бити један од погледа на развој руско-српске лексикографске мисли у овом периоду. Наша пажња у овом раду усмерена је на анализу макроструктуре и микроструктуре ова два речника и њихов међусобни однос.

Кључне речи: руско-српска лексикографија, лексикографска концепција, макроструктура, микроструктура, фонетски, граматички и семантички ниво.

\section{0. Увод}

0.1. Сам почетак XX века, када Речник руско-српски М. Анђелковића излази из штампе (1903) неколико година пре Примера Р. Кошутића, период је када у двојезичкој руско-српској лексикографији већ постоје речници (Н. Глушчевић, Ј. Илић, А. Васиљевић, Т. Стојановић, Л. Мичатек и П. Лавров) (Дамљановић, Кончаревић, 2010: 12-31). Међутим, аутор Речника руско-српског у уводу за свој речник наводи да жели „да попуни празнину” у лексикографској продукцији свога времена јер је као самостални руско-српски речник до тада био издат само речник Т. Стојановића (1900). Паралелно са Речником из штам-

*majamaja5@gmail.com 
пе излази и Практична граматика овог аутора која наилази на оштру оцену А. Белића и П. Протића у Просветном гласнику за 1904. годину. Док Протић указује између осталог да се, кад је о фонетици реч „оваквим описом гласова не може постићи добар успех и утешан резултат”, Белић оштро констатује да је „писац у мало речи мало и рекао” (Просветни гласник 1904: 364-370). Са друге стране, у овом гласилу ни за 1903. нити за касније године нисмо наишли ни на какав коментар или рецензију Анђелковићевог Речника.

Истина, исте године када је Речник био објављен у часопису Нова искра (1903.08.01.) у рубрици Библиографије наилазимо на вест да је међу новим издањима изашао „Речник руско-српски који је израдио Милош С. Анђелковић, професор јагодинске учитељске школе, кандидат кијевске духовне академије”. Дубровачки часопис Сpђ (1903.30.09.) у рубрици Билешке наводи да је „Милош Анђелковић проф у Јагодини (Србија) израдио повећи рјечник руско-српски. Овај рјечник препоручујемо онима који желе учити руски, који језик сваки Србин без по муке за кратко вријеме може изучити". Такође у часопису Дело (1903.07.01.) наилазимо на вест да је „штампан Руско-српски речник Милоша Анђелковића".

Истовремено, часопис Босанска вила (Сарајево) у броју 21. за 1903. годину у рубрици Одјеци и прикази даје опширан приказ новог Анђелковићевог речника из пера В. Бошњаковића:

\footnotetext{
„Граматике су ометале посао учења руског језика, а немање доброг руско-српског речника ометало је још више успеху у овом погледу. Јер ко је хтео добро да изучи руски језик тај га је морао изучавати по немачко-руским и француско-руским речницима. Појавом овог речника дато нам је најлакше и најбоље средство за изучавање руског језика и литературе. Ово је новина не само у српској него и у целој јужно-словенској литератури.

По богатству своје садржине и исцрпном објашњењу речи овај речник спада међу најбоље речнике, а може се смело такмичити и са страним немачко и француско-руским речницима.

Својим оваквим савесним, зналачким и стручним трудом г. Анђелковић је много задужио не само свеколико српство, већ и саме Русе.

Искрено препоручујемо руско-српски речник г. Анђелковића."
}

На основу чињенице да се Просветни гласник, за разлику од других часописа, није осврнуо на овај речник, можемо закључити да је рад М. Анђелковића изазивао опречне ставове његових колега и савременика. Пажњу ипак привлаче и речи руског дипломате у тексту Српски богослови на школовању у Русији у другој половини 19. века (Пилиповић 2012: 75-90): „М. Анђелковић је један од најбољих руских ђака, његови радови који заслужују да буду поменути јесу Руска граматика (1903) и Руско-српски речник (1903)", на основу којих можемо закључити да је Анђелковићев Речник ипак оставио трага у руско-српској лексикографији свога времена.

Опширнији приказ Основног руско-српског речника Р. Маројевића дали смо у овом часопису за 2017. годину у рубрици прикази (Павловић-Шајтинац 
2017: 733-740), али за потребе овог рада издвојићемо неке од сегмената овог речника.

\section{1. МАКРОСТРУКТУРА}

Посматрали смо макроструктуру речника као скуп елемената који указују на општу структуру речника, односно као „самостални систем који поседује унутрашње односе и сложену организацију” (Дубичински 2008: 60).

\section{1. Елементи макроструктуре Речника руско-српског}

Речник се састоји од Увода, напомена на српском и руском језику, и глосара.

У уводу аутор саопштава да је циљ његовог рада побољшање односа Русије и Србије, као и упознавање српских читалаца са руском културом. Напомене се односе на деминутивне и аугментативне суфиксе именица сва три рода и деминутивне суфиксе помоћу којих се, како аутор наводи, „указује презрење онога о чему се говори" (-окъ, -енокъ, -екъ, -икъ, -ещъ; -ка, -енка, -ица; -ко, -ышка, -ие; -ище, -ина, -ища; -ишко, -ишка, -енка).

Речничке одреднице распоређене су по азбучном реду, мада негде наилазимо и на принцип лексичког гнезда.

Можемо претпоставити, мада нема експлицитних доказа, да се аутор определио за делимично коришћење овог принципа следећи пример свог савременика Т. Стојановића, чији речник је објављен неколико година раније, а коме је као узор, између осталих, служио Описни речник живог великоруског језика (Толковый словарь живаго великорусскаго языка) В. Даља, што Т. Стојановић у уводу и наводи „извори Fridrich Boch, Fray, И. Павленский, Х. Ф. Реифъ, В. И Даль”. Прихватајући овај принцип, ни Т. Стојановић ни М. Анђелковић у неким случајевима не следе правила по којима би на првом месту била именица, затим придев, а тек онда глагол и глаголски придев, утврђена средином XIX века приликом рада на Великом Руском речнику у „Правилима за писање речника по принципу лексичког гнезда" (Тихонов 1985:194-200), као ни принцип по коме се у гнездо обједињују речи које имају јасну семантичку везу (Тихонов, ibid). Да се у време настанка овог речника (1903) у нашој говорној средини већ строго води рачуна о распореду речи у лексичко-семантичком гнезду сведочи и критика коју овим поводом J. Илић упућује Т. Стојановићу (Просветни гласник, 1885), а која би се могла упутити и М. Анђелковићу:

„Речник је рађен по двема методама. Негде су и врло сличне речи једнога корена рађене засебно по азбучном реду као на пример разбойникъ, разбойница, разбойничанье, разбойничать, разбойнический и тд. А негде су такве речи представљене у групама. То 
није никаква махна. Али кад се износе речи једнога корена у групама, онда на првом месту мора бити главна реч, па тек за њом долазе друге речи које су од ње постале.”

Као илустрација овом запажању навешћемо неколико примера:

оселокъ, -чекъ, гладило, камен за пробање злата и сребра; не(ис)печени слој, део хлеба: парлог, пустош. Осель, магарац; глуп, лењ човек; будала, лењштина.

Осипать, -нуть, -еть, промући, промукнути, пресипнути; Осиплость, промуклост. Осипъ, Јосиф.

У групу макроструктурних елемената спадају и намена речника, критеријум избора лексичких јединица и информација о постојању или одсуству списка скраћеница граматичких или семантичких квалификатора и упутстава кориснику.

Речник руско-српски има карактеристике пасивног речника, као и остали речници овог периода. О оваквој намени речника сведоче, између осталог, речи М. Анђелковића наведене у предговору његове Практичне граматике (1903) којима упућује корисника да, пошто заврши са учењем програма који је он предвидео у својој граматици, „одмах ваља прећи на штиво, преводећи, помоћу мога речника.” Као и други аутори тог периода, можемо претпоставити да је М. Анђелковић у речник укључивао лексеме из текстова предложених у његовој Практичној граматици, али и широки спектар других одредница из сфере свакодневног живота (прачешная, потаскуха) историје (опричник, орда), културе и обичаја (орлянка, опе(ва)ть) у жељи, како је у уводу речника рекао, да „олакша односе Срба са Русима и нарочито помогне Србима да се што више користе производима богате руске књижевности."

Увидом у руско-српске речника тог периода долазимо до закључка да је постојао још један критеријум везан за избор речи које нису улазиле у глосар речника: наиме, није било препоручљиво користити речи које у оба језика имају исто значење, о чему А. Белић пише у рецензији Анђелковићеве Граматике објављеној у Просветном гласнику: „Мора се водити рачуна да се оно што им је заједничко само помене и задржи се на специфичностима језика који се описује" (Просветни гласник, 1904). Овај аутор у рецензији рускосрпског речника Т. Стојановића указује да „нису изостављене из рукописа ни све стране речи које и код Руса и код Срба имају истоветан значај”. Јасно је да тадашњи лексикографски принципи искључују како обраду речничких одредница страног порекла за оба језика тако и одредница које у два језика имају исти графички облик и исто или слично значење. Т. Стојановић у Кратким напоменама свога речника пише:

„Од страних речи које су махом задобиле грађанство у руском језику, а које је требало по примедбама Просветног савета све без разлике изоставити, задржао сам оне које су порушене; а од непорушених - оне које имају другачији нагласак и изговарање". 
Тако он у свој речник уноси егзотизме као што су рецимо Анако́нда и Баоба́бъ. Одступања од ових правила налазимо и код М. Анђелковића који је у свој Речник уврстио, између осталих, лексеме страног порекла: гонорарій, гопъ, горнъ или лексеме словенског порекла идентичне у оба језика: праматеръ, праотецъ и др.

Кад је реч о скраћеницама којима су означени граматички или семантички квалификатори, М. Анђелковић се определио за њихово изостављање, као што је то учинио и П. Протић чији речник је изашао годину дана након Анђелковићевог (1904). Овакав поступак аутора, могло би се закључити, у тадашњој српској двојезичкој лексикографији није био уобичајен, на шта нас наводи и податак да су и Ј. Н. Стевовић - аутор француско-српског речника (Dictionnaire français - serbe), и Ј. Грчић - аутор Немачко-српског речника (1905), штампани у приближно исто време, у свом саставу имали позамашне спискове скраћеница, чак преко три стотине у Грчићевом и око тридесет у Стевовићевом. Скраћенице су унесене и у Руско-српски речник који је изашао неколико година пре Анђелковићевог, аутора Т. Стојановића, где у списку наилазимо на скраћенице граматичких и стилских квалификатора: прид., м., ж., с., вид., зоол., фиг., мат., ирк., форт. и друге.

Из наведеног можемо претпоставити да су у српској двојезичкој лексикографсој пракси скраћенице граматичких или стилских квалификатора и напомене, односно упутства као што су види, упореди већ имале своје место, из чега следи да је једна од мана Анђелковићевог Речника одсуство граматичких квалификатора, а од напомена он користи види, види ову реч, види овај гл. и 1. л.једн.буд.вр.од гл. Један од могућих разлога можда може бити и то да је М. Анђелковић следио В. И. Даља који је у свом великом речнику „одбацио граматичке карактеристике, односно довео их до минимума" (Протченко, 1996: 114-119).

\section{2. Елементи макроструктуре Основног руско-српског Речника}

Састав овог дела речника чине Увод и Упутство Како се служити речником на српском и руском језику, Техничке скраћенице, Списак руске азбуке, Глосар и Најфреквентније скраћенице руског језика. Речничке одреднице су распоређене азбучним редом са по 24-30 одредница двостубично на свакој од 270 страна.

Аутор речника у Уводу напомиње да је његов речник намењен говорницима чији је матерњи језик српски (српскохрватски) а да својом лексиком речник кориснику може помоћи у остваривању комуникације и разумевању како усмених тако и писмених средстава масовног информисања и књижевних текстова. 
Помоћу упутства аутор кориснику олакшава разумевање речничког метајезика дајући му кључ за брже проналажање одговарајуће лексеме, као и њено смештање у граматички и семантички контекст.

Основни критеријум приликом избора речничких одредница којим се руководио аутор Основног речника јесте учесталост употребе речи, савременост појма који изражава (прво издање настало је у време постојања СССР-а) и творбена могућност речи. Аутор је у свој речник уврстио и фреквентне речи страног порекла независно од тога да ли у српском језику имају идентично/ слично значење или не, као што су метрополитен, курорт, парламент. Нису укључене у речник застареле, некњижевне и жаргонске речи.

Р. Маројевић као и други савремени аутори даје списак скраћеница за граматичке квалификаторе (несври., нема мн., прид, обл., прошл.) и напомене које имају функцију упутства, обавештења и ограничења (в. - види, уп. - упореди, супр. - супротно, об. - обично, само у множини), које имају важну улогу у „проширивању функционалне моћи речника” (Дубичински, 2008).

Овај аутор даје и списак најфреквентијих скраћеница у руском језику на тај начин снабдевајући корисника информацијама важним за разумевање савременог усменог говора и писаних текстова. Списак садржи 36 скраћеница као што су в. - век, вв. - векови, д. (дом) - зграда (у адреси), кв. (квартира) - стан (у адреси), млн. - милион и др.

\section{2. МИКРОСТРУКТУРА}

Под микроструктуром речника посматрали смо питања везана за конструкцију речничког чланка, као одвојеног система на више нивоа који подразумева фонетске, граматичке, семантичке, употребне, стилске, илустративне и друге информације о речничкој јединици.

\section{1. Фонетски ниво}

Упркос томе што се у руско-српски речницима који су претходили његовом - А. Васиљевића (бере́чь, бреди́тъ), Ј. Илића (гроза́, ходи́ть) и Т. Стојановића - поштује принцип акцентовања речничких одредница, као што ради и аутор француско-српског речника, како Стевовић, који осим нормиране акцентуације одредница даје и фонетску транскрипцију (équerre [é-kè-re]) М. Анђелковић не даје фонетско-акценатску информацију о речничким одредницама, што представља, по нашем мишљењу, један од основних недостатака овог речника.

Кад је реч о фонетско-акценатском нивоу Основног руско-српског речни$\kappa a$, све речничке одреднице су доследно акцентоване, указано је на померање 
акцента у падежима множине именица (о́рден-ордена́, волна́ - во́лны, го́луб - го́луби - голубе́й, доска́ - до́ски - доска́м), у парадигматским облицима глагола (останови́ть - остано́вишь, учи́ть - учи́ - у́чишь - у́чат) и др. Присуство фонетске информације подвлачи дидактичку вредност овог речника.

\section{2. Граматички ниво}

На граматичком нивоу, М. Анђелковић у складу са лексикографским правилима даје променљиве именске речи у номинативу, мада у неким случајевима као посебну одредницу даје множински облик именица прадедъ, $n p a d e d b l$, или падешки наставак за устаљени идиом особнякъ, -комъ, има и случајева када аутор указује на неке падешке облике појединих лексема: двухъ, 2. и 7. падеж од два.

Приликом даљег разматрања граматичког нивоа опширније смо се задржали на лексикографској обради глагола, наиме, како у чланку Лексикографски поступак у речницима САНУ и ЈАЗУ наводи И. Грицкат-Радуловић. „пажљиво обрађени глаголи показују до каквих скривених слојева мора доћи лексикограф да би извукао на површину оно што је семантички битно" (Грицкат-Радуловић, 1981: 3-23).

Основни облик глагола представљен у посматраном речнику јесте инфинитив, мада у неким случајевима аутор даје и друге облике, најчешће прво лице једнине садашњег или будућег времена, или облик за заповедни начин:

вою, 1. л. једн. вр. сад. од гл. выть. види выть.

воюю, војујем, ратујем.

вотру, 1. л. једн. буд. вр. д гл. втереть види втереть

вошью, ушићу, зашићу.

ору, 1. л. једн. вр. сад. од гл. орать (види овај гл.)

орать, викати (из свег грла), букати, рикати, урлати; орати.

орю, 1. л. једн. вр. сад. од гл. орать. види овај глаг. (изузевши прва 4 значења).

поезжай, иди, полази, одлази, држи (десно, лево) - 2 л. једн. зап. начина од поехать (види ову реч)

потрудиться, потрудити се, постарати се. потрудитесь потрудите се, будите тако добри.

пошель, - шла, - шли, терај, одлази, одлазите, марш, торњај се, чисти се, вуци се, вуците се, одлазите; чистити се; отишао, пошао, отишли, пошли; терај, брже; напред, даље. 
Р. Маројевић глаголске одреднице даје доследно у складу са савременим лексикографским правилима, наиме: оне су дате у инфинитиву, следе морфолошки наставци за прво и друго лице једнине и треће лице множине садашњег времена, квалификатор вида и рекцијске допуне „у виду заменица за лица или ствари у одговарајућем падежу, односно предлошко-падешкој конструкцији које су услов за реализацију неког од значења" (Гортан-Премк, 1980: 110).

Разматрајући категорију вида која по речима Ремчукове „утиче на оштрину и прецизног и експресивног изражавања лексичког смисла" (Ремчукова, 2005: 32-35), видимо да Анђелковићеви савременици из времена пре појаве Кошутићевог речника ово питање решавају на следећи начин: А. Васиљевић видске парове даје заредом у истом ступцу (Впря'тать, Пря'тать; Вспыли́ть, Пыла́ть) упркос томе што други члан видског пара не одговара азбучном редоследу. Ј. Илић примењује исти принцип (Внести́, Нести́). Ово питање Т. Стојановић решава на тај начин што углавном не врши лексикализацију (односно не указује на промену или нијансу у значењу) другог члана видског пара, већ напоменом вид. указује на несвршени глаголски облик и даје дефиницију свршеног облика, као у примеру: Ба́цать изненада одапети, избацити, опалити (пушку и т.д.); -ся, скрхати се, лупити, љоснути, треснути, стропоштати се, (с треском); тући се. Бацни́ть, II, вид. Ба́цать. М. Анђелковић, као и Т. Стојановић указује на само постојање видског пара напоменом види.

Кад је реч о објашњењу, односно дефиницији, аутор користи различите методе: у неким случајевима значење несвршеног облика објашњава значењем свршеног глаголског облика, као у примерима:

\begin{tabular}{|l|l|}
\hline воцаряться види воцариться & зацарити се, прогласити се за цара. \\
\hline впутывать види впутать & уплести, запести, сплести \\
\hline вплетать види вплесть & уплести, замрсити. \\
\hline
\end{tabular}

Негде на значење свршеног облика указује значењем несвршеног облика:

\begin{tabular}{|l|l|}
\hline восхитить види восхищать. & \\
\hline восхищать & $\begin{array}{l}\text { грабити, отимати, узимати: заносити, усхићи- } \\
\text { вати, задивити, обрадовати кога. }\end{array}$ \\
\hline остановить види останавливать & \\
\hline останавливать & $\begin{array}{l}\text { заустављати, задржавати, обустављати, зауз- } \\
\text { давати, прекраћивати, сметати, прекидати, } \\
\text { стајати на пут. }\end{array}$ \\
\hline
\end{tabular}


Осим указивања на видске парове напоменом види, М. Анђелковић користи и метод непосредног увођења суфикса, односно имперфектизације у истој речничкој одредници, као у случајевима:

\begin{tabular}{|l|l|}
\hline осили(ва)ть & са(над)владати, надјачати, покорити, победити, одолети \\
\hline опут(ыв)ать & $\begin{array}{l}\text { замотати, завити, у(о)мотати, обавити, преплетати, оплести, } \\
\text { заплести, сплести, замрсити, заручити, окружити, опколити }\end{array}$ \\
\hline
\end{tabular}

Примери које смо навели, по нашем мишљењу, сведоче о томе да је М. Анђелковић посвећиво доста пажње лексикографској обради глагола, мада није успео да изгради доследан механизам презентације, као што се види, није увек исти глаголски вид носилац значења (впутывать види впутать или потребить види потреблять), такође приликом објашњења аутор не указује увек и на разлику глаголског аспекта у излазном језику. Додајмо да на овај начин аутор приказује и непрефиксално-префиксалне парове, као и парове рефлексивних и нерефлексивних глагола.

У Основном руско-српском речнику аутор доследно квалификаторима свр., несврш. и несвр. и сврш. када су у питању двовидски глаголи даје видску карактеристику. Свака глаголска реч има своју дефиницију и упућивање на своју парадигму јер су, како каже Зализњак, „чланови видског пара одвојене речи (свака са својом парадигмом), те стога у речнику подлежу лексикализацији" (Зализњак, 1986: 4-8), док је у загради дат њен аспекатски парњак, као у примеру:

остана́влива||ть, -ю, -ешь, -ют несври. кого что, заустављати; обустављати; прекидати машину заустављати кола (сврш.) останови́ть

останов ||и́ть,-лю, остано́в|ишь, -я сврш. кого, что зауставити; обуставити; прекинути; и́ть станок зауставити алатну машину: и́ть работу прекинути рад (несври. остана́вливать)

Кад је реч о руским двовидским глаголима као што су использовать, характеризовать, исследовать, рекомендовать, атаковать, телеграфировать, ранить, обещзать, завещзать, жениться (Маројевић, 1987: 201), који у српском језику имају посебне облике за сваки вид, поред индекса сври. и несври. помоћу илустрације, аутор кориснику указује на оба вида у српском језику:

атак||ова́ть, -у́ю,у́ешь, у́ют несврu. и сври. кого, что нападати/напасти (yn. напада́ть/напа́сть1); ова́ть врага́ нападати/напасти непријатеља 
Оно што одликује лексикографску обраду глагола у речнику Р. Маројевића јесте то да аутор за сваку глаголску одредницу, осим указивања на деклинацијске наставке за прво и друго лице сингулара и треће лице плурала, аспекатски статус глагола и на крају речничког чланка у загради навођење његовог парног глгола супротног вида, даје и рекцијске допуне помоћу одговарајућих падежких облика заменица кто, что на тај начин указујући на валентност датог глагола, као у више наведеном примеру вынести кого, что: иветы из комнаты или вынести что: испытание. Другим речима чланови видских и непрефиксално-префиксалних парова у складу са законима сваремене лексикографије представљени су „као различите лексичке јединице и у речницима наведени одвојено” (Матвејева, 2010: 54).

\section{3. Семантички ниво}

Када је реч о садржају објашњења, односно о лексичком значењу, задатак лексикографа је да објасни „појам који је категорија мишљења, речју која је знак за тај појам и која истовремено јесте знак у језичком систему" (Тошовић, 1992: 82). Семантизација речничког чланка у речницима како његових претходника тако и у речнику М. Анђелковића вршена је уз помоћ преводних еквивалената и објашњења. Док код А. Васиљевића (Зо́ниткъ - сунцобран, кишобран; Забо́та - брига) и Ј. Илића (Данъ - издат, дат: Дань - данак, пореза, День - дан) најчешће наилазимо само на преводне еквиваленте, већ код T. Стојановића можемо наићи на шири речнички чланак. Тако он, рецимо, за одредницу Арши́нный, прид. од аршина (дуг, широк) -ная ме́ра, мера на аршин; товаръ, роба која се продаје на аршин, тканина од једног аршина широка, осим превода даје објашњење идентификујући значењске елеменате и одређујући поља примене лексеме у оквиру лексичко-семантичког гнезда.

М. Анђелковић у објашњењу значења речничких јединица, осим преводних еквивалената, користи и поступак објашњења помоћу културолошких података (тако, рецимо, захваљујући његовим објашњењима можемо, између осталог, пратити појаве промене значења појединих појмова у руском језику (Филиповић, 1986: 158) као у случају лексеме субботник - суботња молитва за умрле / организовани друштвено-корисни рад), синонимских низова, историјских и фолклорних података, и описних превода. Као илустрације у неким случајевима користи паремије и устаљене изразе, као што су Гороховый шут, Всякое бывает, Всплошь и рядом, Нет худа без добра, Как заварили, так и расхлебывайте, Лучше ногой запнуться, нежели (чем) языком, У семь нянек дитя без глазу, Всякий молодец на свой образеи, Счастливому во всем пай, Терпение и труд все перетрут. По нашем мишљењу, управо богатство илустрација би могло представљати највећу вредност речника М. Анђелковића показујући његов преводилачки и лексикографски осећај за нијансе у 
значењу језичких јединица. Ауторов однос према превођењу - из биографије сазнајемо да се осим наставом руског језика активно бавио и превођењем - можда најбоље илуструје његова интерпретација става познатог још од Марка Цицерона и Хорација nec verbum verbo curabis reddere fidus interpres, који аутор износи у предговору превода Јеванђеља по Матеју, објављеном у часопису Бранич српског или хрватског језика (Анђелковић, 1908): „...морам споменути и то, да сам при преводу обраћао пажњу више на смисао него на речи... тако сам чинио стога, што при преводу и није главно преводити речи него смисао. Али, ипак, ја сам се држао и оног начела: „Верно уколико се може, а слободно уколико је допуштено."

Илустроваћемо Анђелковићев начин објашњења значења лексичких јединица неколиким примерима:

впросонкахъ, у пола спавајући, то је оно стање, кад се пробудимо, па се одмах не освестимо, него смо још сањиви.

Аутор приликом објашњења значења лексичке јединице впросонкахъ користи описни превод, тражећи од корисника да својим личним искуством учествује у дефиницији појма.

опеша(и)ть, изгубити коња и остати пешке; уморити се од трчања, ићи полако (једва ноге вукући); по (у)-плашити се, збунити се, престрашити се, упрепастити се, убезекнути се; извадити из леда, исећи лед унаоколо ћускијом -шиться, сићи с коња, ићи пешке (марширати).

Објашњавајући значење полисемичног глагола опеша(и)ть аутор предлаже три значења и за свако од њих даје синонимске низове.

орель, орао, северно сазвездије, историјски пехар (кондир) Петра великог; грб руске државе; телал, онај што купује старудије, прекупац; име псета или коња; земљорадник, онај што плужи; варош у Русији.

Пример лесикографског објашњења именице орел(ъ), сведочи о типичном за М. Анђелковића начину семантизације речничког чланка. Наведено је више значења из области астролгоије, историје, географије и свакодневног живота.

Следећи примери сведоче да М. Анђелковић у свом речнику осим значења појединих речи даје и опис обичаја и народних игара. Други пример сведочи о томе да у датом контексту глагол има пренесено значење и аутор на њега указује. 
орлянка, врста игре помоћу новца; новац се баца у вис, и ако падне тако, да је она страна на којој је орао горе, онда добија онај који баца новац у вис. Добила је име по орлу који је на новцу.

опе(ва)ть, код Руса је обичај, да девојке за време свадбе у песмама нападају (грде) младожењу и законике, те на тај начин изнуђавају новац, па кад што добију, онда их у песмама хвале; отуда овај глагол значи: грдити, ружити, осуђивати, кудити (крпити).

Навешћемо још један пример Анђелковићевог начина богате семантизације речничког чланка.

опричнина, привилегија, искључиво (преимућствено) лично право над каквим имањем; лична, телесна стража (гарда) Ивана IV; део државног имања који је при Ивану Грозном припадао царевом двору, царева (лична) сопственост. Опричникъ, -чной, телохранитељ, лични царски стражар при Ивану IV, гардист; прогнаник, протераник, онај што је искључен, сељак без земље (сирома), пролетаријат. Опричъ, осим, ван, башка, засебно, оделито, особито, не рачунајући, изузимајући, преко мере, прекомерно, сувише, напоље, боље.

Аутор указује на податке из историје средњовековне Русије, и за сваког члана лексичко-семантичког гнезда даје више синонима; у случају лексеме Оприч(ъ) наведено их је чак тринаест. Овакав начин лексикографског описа одредница, по нашем мишљењу, свој мотив има у уводној напомени на почетку речника, у којој аутор пише: „Циљ рада је да се побољшају односи Русије и Србије, као и упознавање Српских читалаца са руском културом". Закључак до кога можемо доћи јесте да М. Анђелковић није желео да корисницима речника преда само пуки појмовник страних речи преведених на српски језик, већ и да их приближи руској традицији и култури јер „националне и културне специфичности језичких јединица имају велику улогу у преводној (и лексикографској делатности), на тај начин преводилац (и лексикограф) у том контексту представља се не само као посредник између два језика, већ и као посредник између две културе" (Дубичински, 2008: 101). Речник М. Анђелковића богат је оваквим примерима.

Р. Маројевић у свом речнику користи метод преводне еквиваленције, систематски илуструјући примере конкретном употребом дате речничке јединице у синтагмама или реченицама, упућујући на валентност речи и колокативне ситуације. Особиту пажњу аутор посвећује неподударању лексичке спојивости руских и српских језичких јединица. Ради бољег разумевања значења лексичких јединица аутор користи синониме и антониме упозоравајући такође и на посебно значење полисемичних или хомонимичних лексема. Акценат је стављен 
и на случајеве међујезичке хомонимије. Као лексикографске илустрације аутор користи устаљене изразе у руском језику. У складу са Апресјановљевом теоријом лексикографског портретисања речничке јединице, Маројевић даје „семантичку и граматичку информацију о речи, карактеристике њених комуникативних, прозодијских, синтаксичких и морфолошких особина, а такође и информацију о семантичким везама са другим значењима у речнику упућујући на синониме и хомониме" (Апресјан, 2006: 151-161) у условима двојезичког речника. Другим речима, осим унутрашњих семантичко-граматичких односа улазног језика, аутор у решавању основног задатка двојезичког речника успоставља везу између лексикографских портрета речничких јединица улазног језика и њихових семантичких еквивалената.

\section{3. ЗАКЉУЧНА РАЗМАТРАњА}

Закључујући овај краћи осврт на лексикографске концепције два речника који припадају различитим етапама развоја руско-српске лексикографије и указујући на њихове разлике можемо у кратким цртама наслутити пут који је пређен.

3.1. На макроструктурном нивоу примећујемо да су промењени елементи који су укључени у састав речника, као и његова намена, тип, критеријум за избор речничких одредница и, додали бисмо, ниво предзнања страног језика претпостављеног корисника. Макроструктура савременог речника садржи повећан број тематских јединица којима аутор успоставља ближу комуникацију са својим претпостављеним корисницима дајући одговоре и на друга могућа питања а не само на питање - шта ова реч значи?

3.2. На микроструктурном нивоу осим преводног еквивалента као основног елемента двојезичког речника обавезно се уводе фонетска, морфолошка, граматичка и синтаксичка информација. Семантизација одреднице померила се од синонимског низа ка систематском указивању на унутрашње и спољне семантичке односе како у улазном језику тако и на међујезичком нивоу, а лексикографска илустрација доноси устаљене изразе савременог језика који имају своју живу примену у свим облицима комуникације.

3.3. На нивоу укупне орагнизације речника могли бисмо рећи да савремени речници и речник Р. Маројевића, као њихов експонент у овом разматрању, представљају компактну целину у којој сви унутрашњи системски распоређени елементи међусобно живо кореспондирају задржавајући при том све своје индивидуалне особине.

Додајмо на крају и данас актуелне речи П. Мајзнера објављене у Просветном гласнику 1904: „Који ће речник узети ученик није, дакле, проста ствар 
као што се чини. Разни речници неизбежни су део сваког апарата за учење сваког језика. Без доброг таквог апарата немогуће је ни учити ни служити се неким језиком, па ни матерњим. Човек који чита, ако је без речника од сваке руке, личи на воденицу без воде... Школе и друштва, где се негује руски језик, ваља да имају што год је само могуће већи речнички апарат, који ће стајати на услузи наставницима и другим члановима."

ИЗВОРИ

Анђелковић 1903: М. Анђелковић. Речник руско-српски, Београд: штампарија Мите Стајића.

Васиљевић 1871: А. Васиљевић. Учитељ рускога језика (речник руских речи), Београд: Државна Штампарија.

Грчић 1905: Ј. Грчић Српско-немачки и немачко-српски речник, Нови Сад: Српска књижарница браће Поповић.

Илић 1883: Ј. Илић Руска граматика за српске школе (речник за примере у граматици), Београд: Краљевско-српска државна штампарија.

Маројевић 2016: Р. Маројевић. Основни руско-српски речник, Бања Лука: Апеирон.

Стевовић 190?: Ј. Стевовић Франиуско-српски речник, Београд: Геца Кон.

Стојановић 1891: Т. Стојановић Ручни речник руско-српског језика, Београд: Књижара Т. Стојановића,

\section{Часописи}

Дело 1903 лист за науку књижевност и друштвени живот - Белешке, Београд 01.07. књ. 28 св. 2279

Нова искра 1903 илустровани часопис - Библиографије, Београд 01.08. V/8 32

Cрђ 1903 лист за књижевност и науку - Билешке, Дубровник 30.09. II/18 871

\section{ЛИТЕРАТУРА}

Анђелковић 1908: М. Анђелковић. Превод Јеванђеља по Матеју, предговор, Јагодина: Бранич српског или хрватског језика II/3 1-12.

Апресјан 2006: Ю. Д. Апресян. Языковая картина мира и системная лексикография, Москва: Языки славянских культур 151-161. 
Павловић-Шајтинац М., О две лексикографске...; Српски језик ХХІІІ, 2018, стр. 719-734 733

Белић 1904: А. Белић. Практична руска граматика Милоша Анђелковића, Београд: Просветни гласник IV 364-366.

Бошњаковић 1903: В. Бошњаковић. Граматика и речник (оцене и прикази), Сарајево: Босанска вила 21-22/355

Гортан-Премк 1980: Д. Гортан-Премк. О граматичкој информацији и семантичкој идентификаци у великом описном речнику, Београд: Нau језик XXIV/3 107-114.

Грицкат-Радуловић 1981: И. Грицкат-Радуловић. Лингвистички поступак у речницима САНУ и ЈАЗУ, Београд: Наш језик XXV/1-2, 3-23.

Дамљановић, Кончаревић 2010: Д. Дамљановић, К. Кончаревић Настава и Методика наставе руског језика у Србији у XIX и XX веку - прилози за историју, Београд: Чигоја 12-31.

Дубичински 2008: В. В. Дубичинский Лексикография русского языка, Москва: Наука 60, 101.

Зализњак 1987: А. А. Зализняк. Грамматический словарь русского языка: Словоизменение, Москва: Русский язык (треће издање), 4-8.

Илић 1885: Ј. Илић. Реферат о руско-српском речнику Тасе Стојановића, Београд: Просветни гласник 196-199.

Мајзнер 1904: П. Мајзнер. Увод у изучавање руског језика с нарочитим обзиром на школе и самоуке, Београд: Просветни гласник, 76-77.

Маројевић 2006: Р. Маројевић. Граматика руског језика, Београд: Завод за уџбенике и наставна средства 201.

Матвејева 2010: Т. В. Матвеева. Полньй словарь лингвистических терминов, Ростов на Дону: Феникс 54.

Пилиповић 2013: Р. Пилиповић. Српски богослови на школовању у Русији у другој половини 19. века. - према оцени руског царског дипломате (1. део), Београд; Баштине 1, 75-90.

Протић 1904: П. Протић. Реферат о практичној руској граматици М. Анђелковића, Београд: Просветни гласник IV 366-370.

Протченко 1996: И. Ф. Протченко. Словари русского языка: Краткий очерк, Москва: РОУ 114-119.

Ремчукова 1994: Е. Н. Ремчукова Лексическая и грамматическая адаптация двувидовых глаголов в современном русском языке // Проблемы функционально-семантической грамматики. Mатериалаы Всесоюзной научно-методической конференции, Москва: РУДН $32-35$. 
Тихонов 2001: А. Н. Тихонов. Слово в грамматике и в словаре, Москва: Цитадель 194-200.

Тошић 1992: Б. Тошић. Преводна семантизација у двојезичном речнику, Београд: Филолошки факултет (необјављена докторска дисертација) 83.

Филиповић 1986: R. Filipović. Teorija jezika u kontaktu, Zagreb: Jugoslavenska akademija znanosti i umjetnosti, Školska knjiga 158-159.

\title{
ON TWO LEXICOGRAPHICAL CONCEPTS
}

\begin{abstract}
Summary
This paper explores the lexicographical concepts of Rečnik Rusko-Srpski (Anđelković, 1903) and Osnovni Rusko-Srpski Rečnik (Marojević, 2016) within their contemporary lexicological environments. Bearing in mind that over a century separates these dictionaries, it is to be hoped that a comparative structical analysis will provide insight into the development of russo-serbian lexicographic approaches. The area of particular focus is laid on a comparative analysis of the dictionaries' macro- and microstructure.

Key words: russo-serbian lexicography, lexicographical concepts, macrostructure, microstructure, phonetic, grammatical and semantic levels
\end{abstract}

Maja V. Pavlović-Šajtinac 